\title{
Asymptomatic Bacteuria among Healthy Cohort Using Dipstick Urinalysis from a Tertiary Health Care Facility in South East Nigeria
}

\author{
Onyeka Chukwudalu Ekwebene and Simeone Tyotswam Yanmeer
}

\section{ABSTRACT}

Dipstick urinalysis is a simple and cost effective method for screening of urinary abnormalities, thus enabling early detection and prompt management of renal pathologies. The aim of the study was to determine the pattern of urinalysis profile among apparently healthy cohorts using medical doctors of Nnamdi Azikiwe University Teaching Hospital. One hundred (100) medical doctors aged 20 to 50 years were selected through convenience sampling in a descriptive cross sectional study from August 20, 2020 to September 10, 2020. Ninety-One $(91 \%)$ had their urine tested with dipstick test strips by Wellkang Ltd. Abnormal urinary findings occurred in $48(52.8 \%)$ of the subjects which were blood $5(5.50 \%)$, glucose 8 $(8.80 \%)$, protein $15(16.50 \%)$, nitrite $10(11.00 \%)$, leucocyte $6(6.60 \%)$ and Ascorbic acid $4(4.40 \%)$. The prevalence of urine abnormality was higher in the 25-30year age group $(\mathbf{4 8 . 4 \%})$, though not statistically significant $(\mathbf{P}>0.05)$. No significant association existed between $\mathrm{pH}$ and urine abnormality $(p=0.5)$. No significant association existed between specific gravity and urine abnormality $(p=0.5)$. It was concluded that the prevalence of urine abnormalities was significantly high $(\mathbf{5 2 . 8 \%})$ with proteinuria and $(11.0 \%)$ nitrites being the commonest abnormalities. Routine dipstick urinalysis is a cheap and simple method for early identification of urine abnormalities in apparently healthy cohorts using medical doctors and a positive dipstick test for proteinuria should prompt further evaluation for the presence of kidney disease. It is recommended that Urinalysis should be instituted as a routine test for medical doctors in hospitals because of its importance in disease surveillance.

Keywords: Urinalysis, Dip stick, Urinary tract infection, Kidney.
Published Online: December 9, 2020

ISSN: $2593-8339$

DOI: $10.24018 /$ ejmed.2020.2.6.567

Onyeka Chukwudalu Ekwebene * Faculty of Medicine, Nnamdi Azikiwe University, Nigeria.

(e-mail: chukwudaluonyeka@gmail.com) Simeone Tyotswam Yanmeer Faculty of Public Health and Applied Human Sciences, Kenyatta University, Kenya.

*Corresponding Author

\section{BACKGROUND}

Urinalysis refers to the chemical analysis of urine. However, it can be defined as identification or separation of ingredients of a substance. In practice, routine urinalysis refers to (1) macroscopic analysis which includes assessment of physical characteristics and chemical analysis (2) Microscopic analysis for formed elements [1].

From historical perspective, the significance of urinalysis in diagnostic medicine came to limelight over a century ago when William Roberts, an English Physician published the first paper on the observation of bacteria in fresh urine [2]. Moreover, the first extensive description of the use of urine for diagnostic purpose came from Hippocrates, who in his prolific writing stated that bubbles on the surface of urine indicates kidney disease and long standing illness as a result of high concentration of protein [3]. The analysis of urine includes physical, chemical, and microscopic examination for the diagnosis of genitourinary, metabolic, endocrine, and genetic disorder [4]. Invariably, culture result of carefully obtained urine sample is considered the gold standard for the diagnosis of urinary tract infection [5].

The most frequent reoccurring question for renal medicine in underdeveloped countries is how to create strategic plans that can detect as early as possible those subjects who are at risk of developing renal disease later in life. This will help to create individual-oriented preventive measures that will limit the need for dialysis and transplantation. The cost effective and cheap way of screening apparently healthy individuals is urinalysis and several studies have been made using reagent strips, recording their effectiveness in identifying urinary abnormalities at relatively low cost [6].

The most commonly employed technique worldwide for detecting UTI is by using diagnostic dipstick, which measures parameters like protein, leukocyte esterase, blood and nitrate reductase levels [7]. A more reliable but timeconsuming technique of bacterial culturing is preferred, involving the use of appropriate media for selected bacterial growth [8]. However, this microbiological assay has the limitation of requiring a minimum of 48 hours to make observations from the culture plates, to ascertain the presence and levels of bacteriuria. Furthermore, the inability of this technique to detect and identify viable but non-culturable microbes may exclude some pathogenic bacteria, which might later cause symptomatic bacteriuria [9]. The occurrence of such viable but nonculturable microbes has been reported for many Gram-negative 
bacteria, including human pathogenic E. coli which is the commonest pathogen, causing more than $80 \%$ of UTIs [10]. In other words, there is the need for a more reliable and faster method for UTI diagnosis.

The three major steps of urine formation are Glomerular filtration, Tubular Reabsorption and Tubular Secretion. In Glomerular filtration, blood flows into the glomerulus via the afferent arteriole and filterable components of blood like water, glucose, amino acids, sodium chloride and urea move from the glomerular capsule through the bowman's capsule into the nephron. The fluid filtered is called the glomerular filtrate. Non-filterable components like cells, serum albumins exit in blood through the efferent arteriole. In Tubular reabsorption, there is active or passive extraction of solutes and water from the tubular fluid into the renal interstitium and then subsequent transport into the bloodstream. Tubular Secretion is the process of active transport of materials from the peritubular capillaries to the renal tubular lumen [11].

A study demonstrated that haematuria next to proteinuria was a potent predictor of end-stage renal disease (ESRD) with male gender being a significant risk factor. However, it has been shown that up to $50 \%$ of the long-term sequalae of occult UTI in young children appear preventable by urine testing. Early detection of renal disease which may progress rapidly or slowly to ESRD, depending on the nature of the disease, may be an important strategy for preventing chronic renal disease in a resource limited setting where dialysis and renal replacement therapy (RRT), the standard management protocol for ESRD are inaccessible because of non-availability of funding and donors [11].

Doctors were chosen, as they form an important part of the healthcare team and have increased risk of having abnormal urine components. Also, medical doctors once trained, are in a better position to help the other groups at risk resolve basic health issues with regards to the genital tract diseases. Furthermore, there is paucity of baseline epidemiologic data on routine dipstick urinalysis among medical doctors and hence, the prevalence of urine components abnormality as detected by the dipstick urinalyis is being studied so as to establish early intervention(s). Dipstick Urinalysis is a non-invasive method that aids the early detection of urinary pathologies.

The objective of this study is to determine the prevalence of urine abnormality among medical doctors, to determine the most prevalent Dipstick Urinalysis parameter among the study population, to determine the components of urine that shows abnormality and to determine the association of urine abnormality with respect to age, $\mathrm{pH}$, specific gravity, genotype and blood group.

\section{METHODOLOGY}

\section{A. Study Area}

The study was conducted at the Nnamdi Azikiwe University Teaching Hospital (NAUTH), Nnewi. Nnamdi Azikiwe University Teaching Hospital (NAUTH) is a tertiary health institution located at Nnewi-Ojoto-Oba Road, Nnewi, Nnewi North LGA of Anambra State, South-East Nigeria.
Nnewi is the second largest city in Anambra State in south-eastern Nigeria [12]. As of 2006, Nnewi has an estimated population of 391,227 according to the Nigerian census. The city spans over 1076.9 square miles $(2,789$ $\mathrm{km}^{2}$ ) in Anambra State [13]. NAUTH provides a wide range of medical, surgical, diagnostic, out-patient, rehabilitative and support services to a catchment population of about 30,994,559. It has a functional Accident and Emergency Unit and provides 24-hour emergency services all year round [14].

\section{B. Study Design}

The study is descriptive and cross-sectional which employed 100 medical doctors from Nnamdi Azikiwe University Teaching Hospital exempting female doctors who was already on their menstruation in the period of this study.

\section{Sample Size Determination}

The following formula [15] were used to develop the sample size:

$$
n=\frac{Z^{2} P Q}{D^{2}}
$$

where

$n=$ Minimal sample size.

$Z=$ Standard normal deviation at $95 \%$ confidence level which is 1.96 .

$P=$ Prevalence $=5.25 \%=0.0525 \%[16]$

$Q=1-\mathrm{P}=1-0.0525=0.9475$.

$D=$ Level of precision required $=0.05$.

$$
\begin{gathered}
n=\frac{1.96^{2} \cdot 0.0525 \cdot 0.9475}{0.05^{2}} \\
n=\frac{3.8416 \cdot 0.0525 \cdot 0.9475}{0.025} \\
n=\frac{0.19109559}{0.025} \\
n=76.4
\end{gathered}
$$

$\mathrm{n}=$ approximately 76 .

Attrition

$10 \%$ of $76=7.6$

$7.6+76.0=83.6$ approximated to 86 .

Thus, minimal sample size is 86 .

However, to improve the reliability of the study results, we increased the sample size to 100.

\section{Sampling Method/Technique}

The Convenience sampling technique was used. Study participants were selected based on the ease of access to them.

\section{E. Study Instruments}

The following instruments were used to collect data for the study:

- Urine dipstick reagent strips (COMBI 11).

- Sterile universal container.

- $\quad$ Surgical Gloves. 
- $\quad$ Paper towel/Tissue paper.

- Data collection forms.

- Blue pens.

- Stopwatch.

- Basins.

\section{F. Data Collection}

Structured questionnaires were used to record the participants biodata (age, gender). Each recruited participant was given a sterile leak-proof universal bottle which was properly labelled with his/her serial number to take home. They were instructed on how to carefully obtain an early morning urine specimen: to clean their perineum, separate the labia for females and collect clean catch midstream urine. The urine specimens were examined using the G. SURETEST $11 \mathrm{~S}$ (manufactured by Wellkang Ltd, England, United Kingdom) which is a dipstick test for eleven components of urine: specific gravity, leucocytes, nitrite, $\mathrm{pH}$, blood, protein, glucose, ascorbic acid, ketones, urobilinogen, and bilirubin. The urine was tested immediately by the researcher with the assistance of two specially trained enrolled doctors. The urine was properly mixed in its container prior to testing. The duration of the test was determined using a timer. The reagent strips were completely immersed into the fresh urine for 1 second and drawn across the rim of the container to remove excess urine. Thereafter, they were held in a flat horizontal position. After 60 seconds, the test strip was compared with the appropriate color chart on the bottle label and the results were recorded. Color changes that appeared only along the edges of the test pads or after more than 2 minutes have passed were of no significance.

\section{G. Data Analysis}

Data entry and analysis was done using Statistical Package for Social Sciences (SPSS) version 20.0

\section{H. Ethical Considerations}

The entire study with special focus on the objectives, and techniques involved were explained clearly to all participants and an informed consent/ethical approval with the number NAUTH/CS/66/VOL.13/VER2/97/2020/027 was obtained from Nnamdi Azikiwe University Teaching Hospital Ethical Committee. The participants were assured of the confidentiality and anonymity of their responses and results which enabled them to provide sincere answers and appropriate urine specimens. The urine specimens were properly discarded immediately after use. Participants were also assured that the information given would be used strictly for academic and/research purposes.

\section{RESULT}

The result of the socio demographic parameter as presented below show that majority of the medical personal sampled are within the age bracket of 25-30 years 44 (48.40\%), male $52(57.10 \%)$, single 59 (64.80\%), Christian $90(98.90 \%)$ and have MBBS as their highest level of educational qualifications $86(94.50 \%)$. Most of them are of Igbos $88(96.70 \%)$, reside in Nnewi 85 (93.40\%) with genotype AA $63(69.20 \%)$ and are majorly of the cadre of house officers $63(69.20 \%)$.

\begin{tabular}{|c|c|c|}
\hline \multicolumn{3}{|c|}{ MEDICAL DOCTORS SAMPLED } \\
\hline $\begin{array}{c}\text { Socio demographic } \\
\text { variable }\end{array}$ & Frequency & Percentage \\
\hline \multicolumn{3}{|l|}{ Age } \\
\hline $20-24$ & 22 & 23.1 \\
\hline $25-30$ & 44 & 48.4 \\
\hline $31-34$ & 16 & 17.6 \\
\hline $35-40$ & 5 & 5.5 \\
\hline $41-44$ & 2 & 2.2 \\
\hline $45-50$ & 2 & 2.2 \\
\hline \multicolumn{3}{|l|}{ Sex } \\
\hline Female & 39 & 42.9 \\
\hline Male & 52 & 57.1 \\
\hline \multicolumn{3}{|l|}{ Marital Status } \\
\hline Married & 32 & 35.2 \\
\hline Single & 59 & 64.8 \\
\hline \multicolumn{3}{|l|}{ Highest Level of Edu } \\
\hline \multicolumn{3}{|l|}{ Qualification } \\
\hline FWACS & 1 & 1.1 \\
\hline FWACP & 2 & 2.2 \\
\hline MBBS & 86 & 94.5 \\
\hline \multicolumn{3}{|l|}{ Religion } \\
\hline Islam & 1 & 1.1 \\
\hline Christian & 90 & 98.9 \\
\hline \multicolumn{3}{|l|}{ Rank } \\
\hline House officer & 63 & 69.2 \\
\hline Resident & 14 & 15.4 \\
\hline Medical officer & 11 & 12.1 \\
\hline Consultant & 3 & 3.3 \\
\hline \multicolumn{3}{|l|}{ Ethnic Group } \\
\hline Efik & 1 & 1.1 \\
\hline Hausa & 1 & 1.1 \\
\hline Yoruba & 1 & 1.1 \\
\hline Igbo & 88 & 96.7 \\
\hline \multicolumn{3}{|l|}{ Place of Residence } \\
\hline Awka & 1 & 1.1 \\
\hline Enugu & 1 & 1.1 \\
\hline Ibadan & 1 & 1.1 \\
\hline Onitsha & 2 & 2.2 \\
\hline Nnewi & 85 & 93.4 \\
\hline \multicolumn{3}{|l|}{ State of Origin } \\
\hline Abia & 5 & 5.5 \\
\hline Anambra & 44 & 48.4 \\
\hline Delta & 2 & 2.2 \\
\hline Ebonyi & 2 & 2.2 \\
\hline Enugu & 14 & 15.4 \\
\hline Imo & 21 & 23.1 \\
\hline Jos & 1 & 1.1 \\
\hline Kogi & 1 & 1.1 \\
\hline Lagos & 1 & 1.1 \\
\hline \multicolumn{3}{|l|}{ Blood Group } \\
\hline A- & 1 & 1.1 \\
\hline$A+$ & 22 & 24.2 \\
\hline AB- & 1 & 1.1 \\
\hline $\mathrm{AB}+$ & 10 & 11.0 \\
\hline B- & 2 & 2.2 \\
\hline $\mathrm{B}+$ & 14 & 15.4 \\
\hline O- & 6 & 6.6 \\
\hline $\mathrm{O}+$ & 35 & 38.5 \\
\hline \multicolumn{3}{|l|}{ Genotype } \\
\hline AA & 63 & 69.2 \\
\hline AS & 28 & 30.8 \\
\hline
\end{tabular}

The abnormal urine components present in the urine samples of the medical personal sampled as presented in Table 2 includes blood $5(5.50 \%)$, glucose 8 (8.80\%), protein $15(16.50 \%)$, nitrite $10(11.00 \%)$, leucocyte 6 (6.60\%) and Ascorbic acid 4 (4.40\%). 
TABLE 2: SHOWING ABNORMAL URINE COMPONENTS OF MEDICAL DOCTORS SAMPLED

\begin{tabular}{|c|c|c|}
\hline $\begin{array}{c}\text { Abnormal urine } \\
\text { component }\end{array}$ & Frequency & Percentage \\
\hline \multicolumn{3}{|l|}{ Blood } \\
\hline Negative & 86 & 94.5 \\
\hline Positive & 5 & 5.5 \\
\hline \multicolumn{3}{|l|}{ Bilirubin } \\
\hline Negative & 91 & 100 \\
\hline Positive & 0 & 0 \\
\hline \multicolumn{3}{|l|}{ Urobilinogen } \\
\hline Negative & 91 & 100 \\
\hline Positive & 0 & 0 \\
\hline \multicolumn{3}{|l|}{ Ketones } \\
\hline $\mathrm{N}$ & 91 & 100 \\
\hline Yes & 0 & 0 \\
\hline \multicolumn{3}{|l|}{ Glucose } \\
\hline Negative & 83 & 91.2 \\
\hline Positive & 8 & 8.8 \\
\hline \multicolumn{3}{|l|}{ Protein } \\
\hline Negative & 76 & 83.5 \\
\hline Positive & 15 & 16.5 \\
\hline \multicolumn{3}{|l|}{ Nitrite } \\
\hline Negative & 81 & 89.0 \\
\hline Positive & 10 & 11.0 \\
\hline \multicolumn{3}{|l|}{ Leucocytes } \\
\hline Negative & 85 & 93.4 \\
\hline Positive & 6 & 6.6 \\
\hline \multicolumn{3}{|l|}{ Ascorbic Acid } \\
\hline Negative & 87 & 95.6 \\
\hline Positive & 4 & 4.4 \\
\hline
\end{tabular}

TABLE 3: SHOWING SPECIFIC GRAVITY OF URINE OF THE MEDICAL

\begin{tabular}{ccc}
\multicolumn{3}{c}{ DOCTORS SAMPLED } \\
\hline Variable & Frequency & Percent \\
\hline Specific gravity $(\mathrm{n}=91)$ & & \\
1.0050 & 1 & 1.1 \\
1.0100 & 2 & 2.2 \\
1.0150 & 11 & 12.1 \\
1.0200 & 10 & 11.0 \\
1.0250 & 18 & 19.8 \\
1.0300 & 49 & 53.8 \\
\hline
\end{tabular}

*Normal range $=1.010-1.030$.

Result above show that though the urine of majority of the medical personal sampled fall within the normal range of specific gravity (1.010-1.030), they were majorly on the high normal side $49(53.80 \%)$.

TABLE 4: SHOWING PH OF URINE OF THE MEDICAL DOCTORS SAMPLED Variable Frequency Percent

\begin{tabular}{cccc}
\cline { 2 - 3 } * & & \\
5 & 34 & 37.4 \\
6 & 54 & 59.3 \\
6.5 & 0 & 0 \\
7 & 2 & 2.2 \\
8 & 1 & 1.1 \\
9 & 0 & 0 \\
\cline { 2 - 3 } Normal range $=4.5-8.0$. & &
\end{tabular}

Table 5 shows that there is no relationship between the presence of urine abnormalities and the socio demographic parameters analysed $(\mathrm{P}>0.05)$.
TABLE 5: CHI-SQUARE ANALYSIS SHOWING RELATIONSHIP BETWEEN URINE ABNORMALITIES AND AGE, BLOOD GROUPS, GENOTYPE AND

\begin{tabular}{|c|c|c|c|c|}
\hline \multicolumn{5}{|c|}{ MARITAL STATUS } \\
\hline Socio & \multicolumn{2}{|c|}{$\begin{array}{c}\text { Presence of Urine } \\
\text { Abnormality }\end{array}$} & $\chi^{2}$-value & P-value \\
\hline Age & Negative & Positive & 4.275 & 0.639 \\
\hline $20-24$ & 14 & 7 & & \\
\hline 2024 & 1 & 0 & & \\
\hline $25-30$ & 27 & 17 & & \\
\hline $31-34$ & 9 & 7 & & \\
\hline $35-40$ & 3 & 2 & & \\
\hline $41-44$ & 1 & 1 & & \\
\hline $45-50$ & 0 & 2 & & \\
\hline \multicolumn{5}{|l|}{ Blood Group } \\
\hline A- & 0 & 1 & 10.020 & 0.188 \\
\hline $\mathrm{A}+$ & 15 & 7 & & \\
\hline AB- & 1 & 0 & & \\
\hline $\mathrm{AB}+$ & 6 & 4 & & \\
\hline B- & 1 & 1 & & \\
\hline $\mathrm{B}+$ & 5 & 9 & & \\
\hline $\mathrm{O}-$ & 2 & 4 & & \\
\hline $\mathrm{O}+$ & 25 & 10 & & \\
\hline \multicolumn{5}{|l|}{ Genotype } \\
\hline $\mathrm{AA}$ & 40 & 23 & 0.372 & 0.486 \\
\hline AS & 15 & 13 & & \\
\hline \multicolumn{5}{|l|}{ Marital Status } \\
\hline Married & 17 & 15 & 1.104 & 0.370 \\
\hline Single & 38 & 21 & & \\
\hline
\end{tabular}

\section{DISCUSSION}

\section{A. Demographic Data of Study Participants}

The result of the socio demographic parameter as presented above showed that majority of the medical doctors sampled are within the age bracket of 25-30 years $44(48.40 \%)$, male 52 (57.10\%), single 59 (64.80\%), Christian $90(98.90 \%)$ and have MBBS as their highest level of educational qualifications 86 (94.50\%). Most of them are of Igbos 88 (96.70\%), reside in Nnewi 85 (93.40\%) with genotype AA $63(69.20 \%)$ and are majorly of the cadre of house officers $63(69.20 \%)$. A total of 91 medical doctors participated in this study. This is closer to that obtained in a study by Ugwuja \&Ugwu (250) [17] but is much lower than that obtained in studies by Fouad $\mathrm{M}$ and Boriae M (2500) [18] and Silverberg D et al (23, 4, 27) [19]. The reason for the variations could be due to the differences in the size of the study population.

\section{B. $\quad$ Prevalence of Urine Abnormality}

An overall abnormal urine analysis (one or more components) was found in 48 urine samples $(52.8 \%)$ in our study. This is comparable to the prevalence of $35 \%$ obtained in a study by Tjale MC [20], but is much higher than the values of $5.25 \%$ and $15.4 \%$ obtained respectively in studies by Oviasu E et al [16] and Khallid \&Haddad [21]. The prevalence of urine abnormality in this study appears to be significantly high, inotherwords if one considers the calculated rate of false positive/transient abnormality of $32.1 \%$ (in the first screening) and $13.8 \%$ (in the second screening) by Fouad and Boraie [18] the persistent abnormality rate could be much lower. Thus, it can be inferred that the prevalence of urine abnormality varies from one study to the other. 


\section{C. $\quad$ The Relationship Between Urine Abnormality and Selected Demographics}

There was no significant relationship between urine abnormality and the socio-demographic parameters analysed $(\mathrm{P}>0.05)$. The results of this study indicated more abnormalities among participants in the age 25-30 years $(48.4 \%)$ even though there was no significant association between the socio-demographic parameters and urine abnormality. This is unlike findings by Oviasu et al [16] in which abnormalities occurred more in the 14-16-year age group. More abnormality among participants with blood group $\mathrm{O}+$ was identified in this study and non in $\mathrm{AB}+$. This study also recorded more abnormalities among participants with AA Genotype and least in AS genotype. Abnormality in urine was more among singles than married participants.

\section{Abnormality in the Urine Components}

In this study, protein was the most frequent urine abnormality identified 15(16.5\%), followed by nitrite $10(11.0 \%)$. The other abnormalities were very few and include leucocytes $6(6.6 \%)$, blood 5(5\%) and ascorbic acid $4(4.4 \%)$.

These findings are comparable to those obtained in a study by Fouad and Boraie [18] which showed that the prevalence of asymptomatic urinary abnormalities among the studied individuals were Hematuria, proteinuria, and leukocyturia in $26.4 \%, 3.8 \%$, and $11.5 \%$ respectively. In the second screening, hematuria and leukocyturia were significantly decreased to $9.8 \%(\mathrm{P}<0.01)$ and $6 \%(\mathrm{P}=0.03)$ respectively, although proteinuria also decreased to $2.6 \%$ but insignificantly.

Our finding was in contrast with that of Khallid and Haddad [21] in which $8.1 \%$ had pyuria, $6.1 \%$ had haematuria and $4.8 \%$ had albuminuria.

However, results of urine components from most studies showed low values and on the other hand our values were higher. The reason for these variations may be due to differences in methodology and sociodemographic characteristics of the study cohort, or due to epidemiologic variations between the study areas [22].

Proteinuria can be a major cause of underlying kidney disease or a transient finding among medical doctors. False positive findings can arise because of mucus, pus, blood, or highly alkaline $(\mathrm{pH}>8)$ and highly concentrated urine; false negative ones, because of diluted urine [23]. In our study, collection of first early morning urine sample helped in excluding orthostatic proteinuria as a cause of isolated proteinuria in medical doctors. High prevalence of proteinuria $(33 \%)$ in our study may indicate early presentation of renal disease as studies in both animal and humans have shown that proteinuria is a mediator as well as a marker of progressive glomerular damage [24]. The levels of proteinuria are one of the strongest predictors for renal function deterioration [25]. Asymptomatic proteinuria warrants further work-up to detect and even prevent ESRD [26].

The prevalence of Leucocyte esterase and nitrite in our study were $6(6.6 \%)$ and $10(11.0 \%)$ respectively. This is comparable with findings by Isezuo et al [27] who found Leukocyte esterase to be present in female participants.
In our study, the prevalence of nitrite was $11.0 \%$. This is in tandem with the findings by Isezuo et al [27] in which Nitrite was the commonest abnormality (12\%).

These differences in urinary abnormalities may reflect susceptibility to prevalent diseases in different locales and other confounding factors. For instance, false positives may be due to exposure to cold, prolonged recumbence, and contamination of urine samples with menstrual blood in females. However, we tried to minimize contamination of urine samples with menstrual blood by excluding females who were menstruating or had recently finished menstruating as at the period of study. Unfortunately, none of our participants with these urinary abnormalities were followed-up to ascertain the level of renal involvement, if any. We believe this would be an interesting research area for future studies.

Result showed that though the urine of majority of the medical doctors sampled fall within the normal range of specific gravity (1.010-1.030), they were majorly on the high normal side 49 (53.80\%).

$100 \%$ of the urine samples had a normal $\mathrm{pH}$ (normal range 4.5-8). There was no significant association between $\mathrm{pH}$ and urine abnormality $(\mathrm{p}=0.5)$.

\section{CONCLUSION}

The prevalence of urinary abnormality among medical doctors of Nnamdi Azikiwe University Teaching Hospital Nnewi is significantly high (52.8\%), as detected by dipstick urinalysis. The most prevalent urine abnormality is protein $(16.5 \%)$. There was no significant association between socio-demographic parameters and urine abnormality $(\mathrm{P}>0.05)$, though the age group 25-30 years showed more abnormalities. We therefore think and stand to be corrected that Routine dipstick urinalysis is a cheap and simple method for early identification of urine abnormalities in apparently healthy medical doctors and a positive dipstick test for proteinuria should prompt further evaluation for the presence of kidney disease.

\section{RECOMMENDATIONS}

- All medical doctors should have routine urine screening programmes for the early detection and treatment of renal diseases.

- Dipstick urinalysis should be performed twice to rule out transient urine abnormalities.

- A widespread dipstick urinalysis screening program should be implemented to determine the exact prevalence of dipstick urinary abnormalities among medical doctors in Nigeria, as there are no studies on the subject.

- More health promotion programs need to be implemented among health practitioners in order to increase the awareness and improve their health behaviours.

\section{COMPETING INTERESTS}

The authors declared that they have no competing interests and no funding for this research work. 


\section{LIMITATIONS OF THE STUDY}

Part of the limitations to this study includes:

- There was no fund for this study because such study should be a prospective study and also urine culture would have been done as well which is capital intensive.

\section{REFERENCES}

[1] Abirami K. Tiwari SC. Urinalysis in Clinical Practice (Akin to Liquid Kidney Biopsy). Journal, Indian Academy of Clinical Medicine. 2001 January-June;2(1-2):1.

[2] Roberts W. On the occurrence of microorganism in fresh urine. Lancet 1881:623-625

[3] Hippocratic writing (Transl J Chadwick, WN mann). Pengium, new ork 1978: pp 232

[4] Haber M.H. Passe prophesy: A brief history of urinalysis. Clin. Lab. Med. 1998: 8(3):415-430

[5] Blake B, Judith CB, Wendy JP, Michad JC, Malinda MG, Dennis D. Can urine clarity exclude the diagnosis of urinary tract infection? 2000: 106 (5): 60-69

[6] Plata, R, Silva, C, Yahmita, J, Perez, L, Schieppati, A, Remuzzi, G 1998, 'The first clinical and epidemiological programme on renal disease in Bolivia: a model for prevention and early diagnosis of renal diseases in the developing countries', Nephrology Dialysis Transplantation, vol. 13, pp. 3034-3036. Retrieved may 3, 2020, from Pubmed database.

[7] WHO (2005) Department of Child and Adolescent Health and Development; Urinary Tract Infections in Infants and Children in Developing Countries in the Context of IMCI. 1-24.

[8] Zorc, J.J., Kiddoo, D.A. and Shaw, K.N. (2005) Diagnosis and Management of Pediatric Urinary Tract Infections. Clinical Microbiology Reviews. 18, 417-422.

[9] Colwell, R. R., (2000). Viable but non-culturablebacteria: a survival strategy. J Infect Chemother. 6, 121-125.

[10] Ronald, A. (2003). The etiology of urinary tract infection: traditiona and emerging pathogens. Dis Mon. 49, 71-82

[11] Iseki K, Iseki C, Ikemja U, Fukiyama K. Risk of developing endstage renal disease in a cohort of mass screening. Kidney Int. 1996; 49 (3); 800-805.

[12] Nnewi. 2016. Available at https://en.m.wikipedia.org/wiki/Nnewi. Accessed 25th August 2020

[13] Nnewi facts and figures. Available at http://www.nacuk.org/factfile.htm. Accessed 25 ${ }^{\text {th }}$ August 2020.

[14] Nnamdi Azikiwe University Teaching Hospital 2016. Available https://NAUTH.org.ng/about-us . Accessed 25 $5^{\text {th }}$ August 2020.

[15] Naing L, et al. Practical Issues in Calculating the Sample Size for Prevalence Studies. Archives of Orofacial Sciences. 2006;1: 9-14

[16] Oviasu E, Oviasu SV. Urinary Abnormalities in asymptomatic adolescent Nigerians. West African Journal of Medicine. 1994 JulSept; 13(3):152-5

[17] Ugwuja EI, Ugwu NC. Urinary Findings in Young Adults in Abakaliki, Nigeria. Nigerian Journal of Clinical Practice. 2008 September; 11(3):275-278.

[18] Fouad M, Boraie M. Prevalence of Asymptomatic Urinary Abnormalities Among Adolescents. Saudi Journal of Kidney Disease and Transplantation. 2016;27(3):500-506.

[19] Silverberg DS, et al. City-wide screening for urinary abnormalities in schoolgirls. Canadian Medical Association Journal. 1973 November 17;109(10):981-985

[20] Tjale MC. The Prevalence of Abnormal Urine Components as Detected by Routine Dipstick Urinalysis: A Survey at A Primary Health Care Clinic in Mankweng Hospital. University of Limpopo; 2009.Polokwane/Mankweng Hospital, South Africa (cited 2019July 21). Available from: $h t t p: / / h d l . h a n d l e . n e t / 10386 / 450$.

[21] Khallid NS, Haddad FH. Routine urine analysis in university candidates: is it worthwhile? Eastern Mediterranean Health Journal 1999;5(1):118-122.

[22] Utsch B, Klaus G. Urinalysis in Children and Adolescents. Deutsches Ärzteblatt International 2014; 111(37):617-626.

[23] Moxey-Mims M: Hematuria and proteinuria. In: Kher KK, Schnaper HW, Makker SP (eds.): Clinical Pediatric Nephrology. 2nd edition. Abingdon, United Kingdom: Informa Healthcare; 2007: 129-139.

[24] Jeff AS, et al. Urinalysis: a comprehensive review. American Family Physician. 2005; 71(6):1153-1162

[25] Iseki K, et al. Proteinuria and the risk of developing end- stage renal disease. Kidney International 2003; 63:1468- 74
[26] Hanif R, et al. Effectiveness of routine urine analysis of patient attending rural health centers in Abbottabad. Journal of Ayub Medical College Abbottabad. 2006; 18:63-4.

[27] Isezuo KO, et al. Urine Dipstick Abnormalities in Asymptomatic Adolescents in Sokoto Metropolis, Sokoto State, North-Western Nigeria. World Journal of Biomedical Research. 2017; 4 (1):35-42.

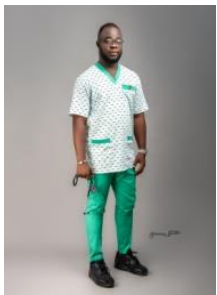

Ekwebene Onyeka Chukwudalu was born in Onitsha, Anambra State, South Eastern Nigeria. He had his primary and secondary school education in nnewi and Eziagu respectively in Anambra state and university in Nnamdi Azikiwe University Awka, where he graduated from the department of Parasitology and Entomology in 2013 as the best male student. He obtained a second degree in same university and graduated in flying colours from the faculty of medicine where he obtained MB; BS (Bachalors in Medicine and Bachalors in Surgery) in 2019. Because of his passion for education he obtained a Post Graduate Diploma in Education from Nnamdi Azikiwe University, Awka in 2019. He obtained an upper credit in the 2010 HADLICEX (HIV/AIDS AND DRUG LITERACY CERTIFICATE EXAMINATION), In $2014 \mathrm{He}$ obtained a general and advanced certificate in occupational Health, Safety and Environment (HSE 2,3) from Project Management Development Center. He has a Professional Development Certificate training in Leadership and Management in Health from University of Washington.

$\mathrm{He}$ is presently working as an assistant doctor in El-norah and Shekinah Glory M-Specialty Hospital Atani. He is also the founder of Sunrise Apparrel Signatures, a registered and fast growing fashion industry. He has 5 articles with a peer reviewed journal.

Ekwebene Onyeka Chukwudalu is a member of Royal Society of Tropical Medicine and Hygiene, member of PAC-NET women health and youths development initiative, member of Malaria Eradication And Safe Health Initiative (MESHI). He was also a facilitator/Resource person who trained principals and head teachers in Anambra State for Covid-19 preventive measures in preparation of school reopening.

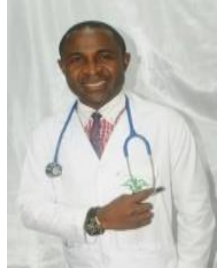

Tyotswam Simeone Yanmeer was born in GbokoNigeria. In 2009, He bagged First class with distinction in Bachelor of Science (BSc) Biotechnology with interest in Pharmacogenomics and Certificate course in Bioinformatics at Manipal University, India, upon completion of his primary and high school in West Africa.

In 2014/2015, he obtained double honors degree with distinction in Doctor of Medicine (MD) and Masters in Public Health (MPH) at DR. Francisco .Q. Duque Medical Foundation $\&$ the Institute of Graduate Studies, Lyceum North-Western University (LNU), Philippines respectively.Currently undertaking his Doctor of Philosophy (PHD) degree in Reproductive Health at the Faculty of Public Health and Applied Human Sciences, Kenyatta University, NairobiKenya.His interest in research prompted him to obtain CITI Certified Program in 2018 \& participated in the Indo-Australian Conference on human variations \& Pharmacogenomics and Indo-USA Workshop on Mitochondrial research \& Medicine in India. He has jointly researched on Malaria Epidemiology in Africa and Water \& Sanitation practices of the coastal community in Pantal district-Dagupan City, Philippines. He worked as Team Lead on NAIIS Project for a wide range of multilateral, bilateral \& Non-governmental agencies including the United Nations (WHO, UNICEF, World Bank), USAID, Center for disease Control, USA, and Global Fund.

In 2019, He was a speaker on maternal health, child health \& Social issues at PARIS World Health Organization (WHO) Simulation Conference held in Paris -France. He also volunteered on pulse polio immunization program as a member of Rotaract club - R. I. Dist. 3180 sponsored by UNICEF, India. 